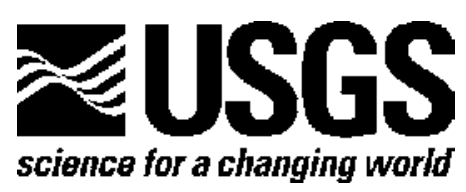

\title{
Simplified Stratigraphic Cross Sections of the Eocene Green River Formation in the Piceance Basin, Northwestern Colorado
}

By John D. Dietrich and Ronald C. Johnson

Open-File Report 2013-1012

U.S. Department of the Interior

U.S. Geological Survey 


\section{U.S. Department of the Interior \\ KEN SALAZAR, Secretary}

\section{U.S. Geological Survey \\ Suzette M. Kimball, Acting Director}

U.S. Geological Survey, Reston, Virginia: 2013

For more information on the USGS-the Federal source for science about the Earth, its natural and living resources, natural hazards, and the environment-visit http://www.usgs.gov or call 1-888-ASK-USGS

For an overview of USGS information products, including maps, imagery, and publications, visit $h$ ttp://www.usgs.gov/pubprod

To order this and other USGS information products, visit $h$ ttp://store.usgs.gov

\footnotetext{
Suggested citation: Dietrich, J.D., and Johnson, R.C., 2013, Simplified stratigraphic cross sections of the Eocene Green River Formation in the Piceance Basin, northwestern Colorado: U.S. Geological Survey Open-File Report 2013-1012, 20 p.
}

Any use of trade, product, or firm names is for descriptive purposes only and does not imply endorsement by the U.S. Government.

Although this report is in the public domain, permission must be secured from the individual copyright owners to reproduce any copyrighted material contained within this report. 


\section{Contents}

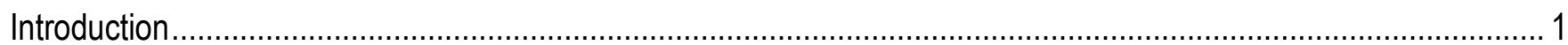

Stratigraphy of the Green River Formation, Colorado and Utah ................................................................. 1

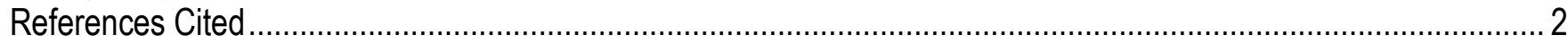

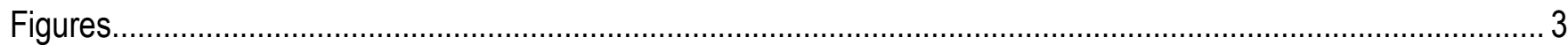

\section{Figures}

Figure 1. Map showing extents of Uinta, Piceance, and Greater Green River Basins and approximate extent of oil shale in the Eocene Green River Formation.

Figure 2. Cross section showing members of the Eocene Green River Formation, stages in the evolution of Lake Uinta, correlation of rich (R) and lean (L) oil shale zones of Cashion and Donnell (1972), and oilyield histograms. Line of cross section is indicated on figure 1.

Figure 3. North-south cross section through the Piceance Basin, northwestern Colorado, showing stratigraphic subdivisions, stages of Lake Uinta as defined by Johnson (1985), and some of the rich and lean zones defined by Cashion and Donnell (1972)

Figure 4. Map showing locations of the 13 stratigraphic cross sections in the Piceance Basin, Colorado ............. 7

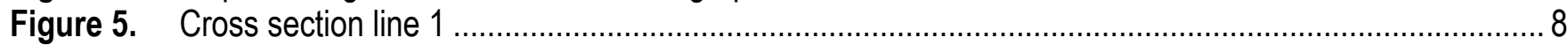

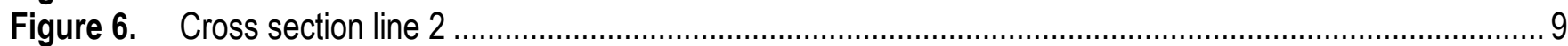

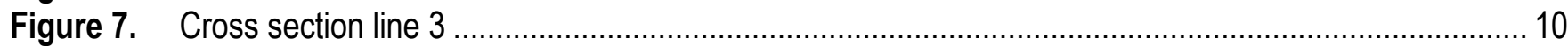

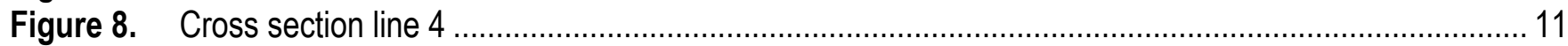

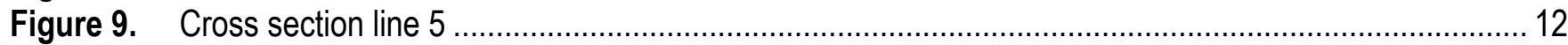

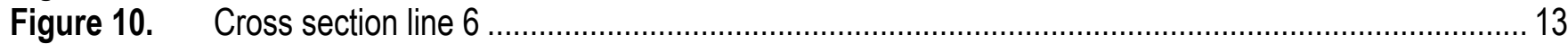

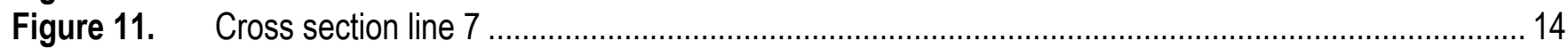

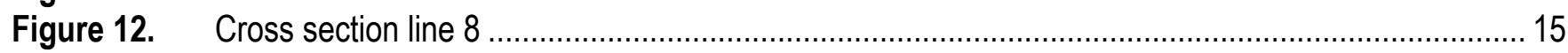

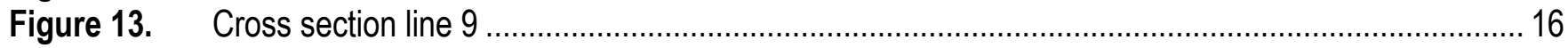

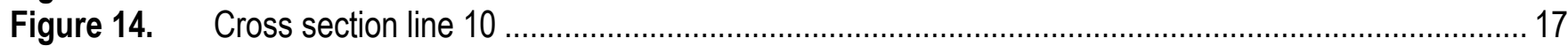

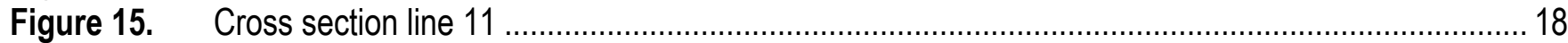

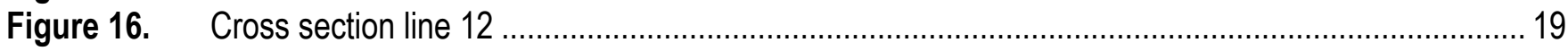

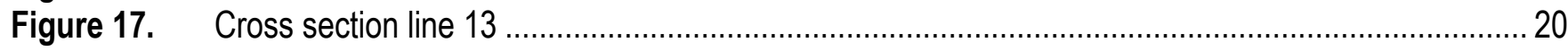

\section{Conversion Factors}

Inch/Pound to SI

\begin{tabular}{|c|c|c|}
\hline Multiply & By & To obtain \\
\hline \multicolumn{3}{|c|}{ Length } \\
\hline inch (in.) & 2.54 & centimeter $(\mathrm{cm})$ \\
\hline inch (in.) & 25.4 & millimeter $(\mathrm{mm})$ \\
\hline foot $(\mathrm{ft})$ & 0.3048 & meter $(\mathrm{m})$ \\
\hline mile (mi) & 1.609 & kilometer (km) \\
\hline \multicolumn{3}{|c|}{ Volume } \\
\hline gallon (gal) & 3.785 & liter $(\mathrm{L})$ \\
\hline gallon (gal) & 0.003785 & cubic meter $\left(\mathrm{m}^{3}\right)$ \\
\hline gallon (gal) & 3.785 & cubic decimeter $\left(\mathrm{dm}^{3}\right)$ \\
\hline
\end{tabular}




\title{
Simplified Stratigraphic Cross Sections of the Eocene Green River Formation in the Piceance Basin, Northwestern Colorado
}

\author{
By John D. Dietrich and Ronald C. Johnson
}

\section{Introduction}

Thirteen stratigraphic cross sections of the Eocene Green River Formation in the Piceance Basin of northwestern Colorado are presented in this report. Originally published in a much larger and more detailed form by Self and others (2010), they are shown here in simplified, page-size versions that are easily accessed and used for presentation purposes. Modifications to the original versions include the elimination of the detailed lithologic columns and oil-yield histograms from Fischer assay data and the addition of ground-surface lines to give the depth of the various oil shale units shown on the cross section.

\section{Stratigraphy of the Green River Formation, Colorado and Utah}

The Green River Formation of the Piceance Basin was deposited in the Eocene Lake Uinta, a long-lived lake that covered much of the Piceance Basin, the Uinta Basin to the west in eastern Utah and westernmost Colorado, and the intervening Douglas Creek arch (fig. 1). Lake Uinta remained a single continuous lake across both basins and the Douglas Creek arch throughout most of its history, and most stratigraphic units can be recognized in both basins (fig. 2). The early stages of the lake are marked by deposition of clay-rich oil shale referred to as the Garden Gulch Member (figs. 2, 3). Oil-shale zones deposited later in the lake's history are carbonate-rich and referred to as the Parachute Creek Member. These oil shale units grade marginward into marginal lacustrine rocks of the Douglas Creek and Anvil Points Members. The names "Garden Gulch," "Parachute Creek," and "Douglas Creek Members" of the Green River Formation were first used by Bradley (1931). The name "Anvil Points Member" of the Green River Formation was first used by Donnell (1953). Sandstones and siltstones containing abundant volcanic debris intertongue with the upper part of the Green River Formation and form units within the Eocene Uinta Formation (Cashion and Donnell, 1974) in the northern part of the basin.

Cashion and Donnell (1972) recognized that the Parachute Creek and Garden Gulch Members could be subdivided into a sequence of oil-rich zones (R-zones) and oil-lean zones (L-zones) that could be recognized throughout much of the central part of the Piceance Basin and eastern part of the Uinta Basin (fig. 2). These zones appear to form approximate timestratigraphic units representing changing rates of organic matter production and preservation that occurred simultaneously throughout Lake Uinta. The rich and lean-zone stratigraphy formed the basis of the recent assessments of in-place oil shale resources in the Piceance and Uinta Basins by the U.S. Geological Survey (Johnson and others, 2010a, 2010b). The lower zones, from the 
L-0 zone through the L-1 zone, are rich in clay and contain little carbonate; these form the Garden Gulch Member (fig. 2). All zones above the L-1 zone composing Parachute Creek Member (fig. 2) are dolomitic. Units above the R-6 zone are, (in ascending order); the B-groove, a lean zone; the Mahogany ledge, the richest oil shale zone in the basin; and the A-groove, another lean zone. The 13 cross sections (locations shown in fig. 4-17) show the distribution of the Green River Formation and the rich and lean zones within them.

\section{References Cited}

Bradley, W.H., 1931, Origin and microfossils of the oil shale of the Green River Formation of Colorado and Utah: U.S. Geological Survey Professional Paper 168, 58 p.

Cashion, W.B., and Donnell, J.R., 1972, Chart showing correlation of selected key units in the organic-rich sequence of the Green River Formation, Piceance Creek Basin, Colorado, and Uinta Basin, Utah: U.S. Geological Survey Oil and Gas Investigations Chart OC-65.

Cashion, W.B., and Donnell, J.R., 1974, Revision on nomenclature of the upper part of the Green River Formation, Piceance Creek Basin, Colorado, and eastern Uinta Basin, Utah: U.S. Geological Survey Bulletin 1394-G, 9 p.

Donnell, J.R., 1953, Columnar section of rocks exposed between Rifle and DeBeque Canyon, Colorado: Rocky Mountain Association of Geologists Guidebook, Field Conference, Northwestern Colorado, p. 14.

Donnell, J.R., 2008, Intertonguing of the lower part of the Uinta Formation with the upper part of the Green River Formation in the Piceance Creek Basin during the late stages of Lake Uinta: U.S. Geological Survey Scientific Investigations Report 2008-5237, 25 p. (Also available at http://pubs.usgs.gov/sir/2008/5237/.)

Donnell, J.R., and Blair, R.W., 1970, Resource appraisal of three rich oil-shale zones in the Green River Formation, Piceance Creek basin, Colorado: Colorado School of Mines Quarterly, v. 65 , p. 73-87.

Johnson, R.C., 1985, Early Cenozoic history of the Uinta and Piceance Creek Basins, Utah and Colorado, with special reference to the development of Eocene Lake Uinta, in Flores, R.M., and Kaplan, S.S., eds., Cenozoic paleogeography of the west-central United States: Rocky Mountain Paleogeography Symposium 3, The Rocky Mountain Section, Society of Economic Paleontologists and Mineralogists, p. 247-276.

Johnson, R.C., 2012, The systematic geologic mapping program and a quadrangle-by-quadrangle analysis of time-stratigraphic relations within oil shale bearing rocks of the Piceance Basin, western Colorado: U.S. Geological Survey Scientific Investigations Report 2012-5041, 35 p. (Also available at http://pubs.usgs.gov/sir/2012/5041/.)

Johnson, R.C., Mercier, T.J., Brownfield, M.E., Pantea, M.P., and Self, J.G., 2010a, An assessment of in-place oil shale resources in the Green River Formation, Piceance Basin, Colorado, chap. 1 of Oil shale and nahcolite resources of the Piceance Basin, Colorado: U.S. Geological Survey Digital Data Series Report 69-Y. (Also available at http://pubs.usgs.gov/dds/dds-069/dds-069-y/REPORTS/69_Y_CH_1.pdf.)

Johnson, R.C., Mercier, T.J., Brownfield, M.E., and Self, J.G., $2010 \bar{b}$, Assessment of in-place oil shale resources in the Eocene Green River Formation, Uinta Basin, Utah and Colorado, chap. 1 of Oil shale resources of the Uinta Basin, Utah and Colorado: U.S. Geological Survey Data Series Report DS 69-BB. (Also available at http://pubs.usgs.gov/dds/dds-069/dds-069bb/REPORTS/69_BB_CH_1.pdf.) 
Mercier, T.J., and Johnson, R.C., 2012, Isopach and isoresource maps for oil shale deposits in the Eocene Green River Formation for the combined Uinta and Piceance Basins, Utah and Colorado: U.S. Geological Survey Scientific Investigations Report 2012-5076, 86 p., 1 plate. (Also available at http://pubs.usgs.gov/sir/2012/5076/.)

Self, J.G., Johnson, R.C., Brownfield, M.E., and Mercier, T.J., 2010, Stratigraphic cross sections of the Eocene Green River Formation in the Piceance Basin northwestern Colorado, chap. 5 of Oil shale and nahcolite resources of the Piceance Basin, Colorado: U.S. Geological Survey Digital Data Series Report DS 69-Y. (Also available at http://pubs.usgs.gov/dds/dds-069/dds069-y/REPORTS/69_Y_CH_5.pdf.)

\section{Figures}




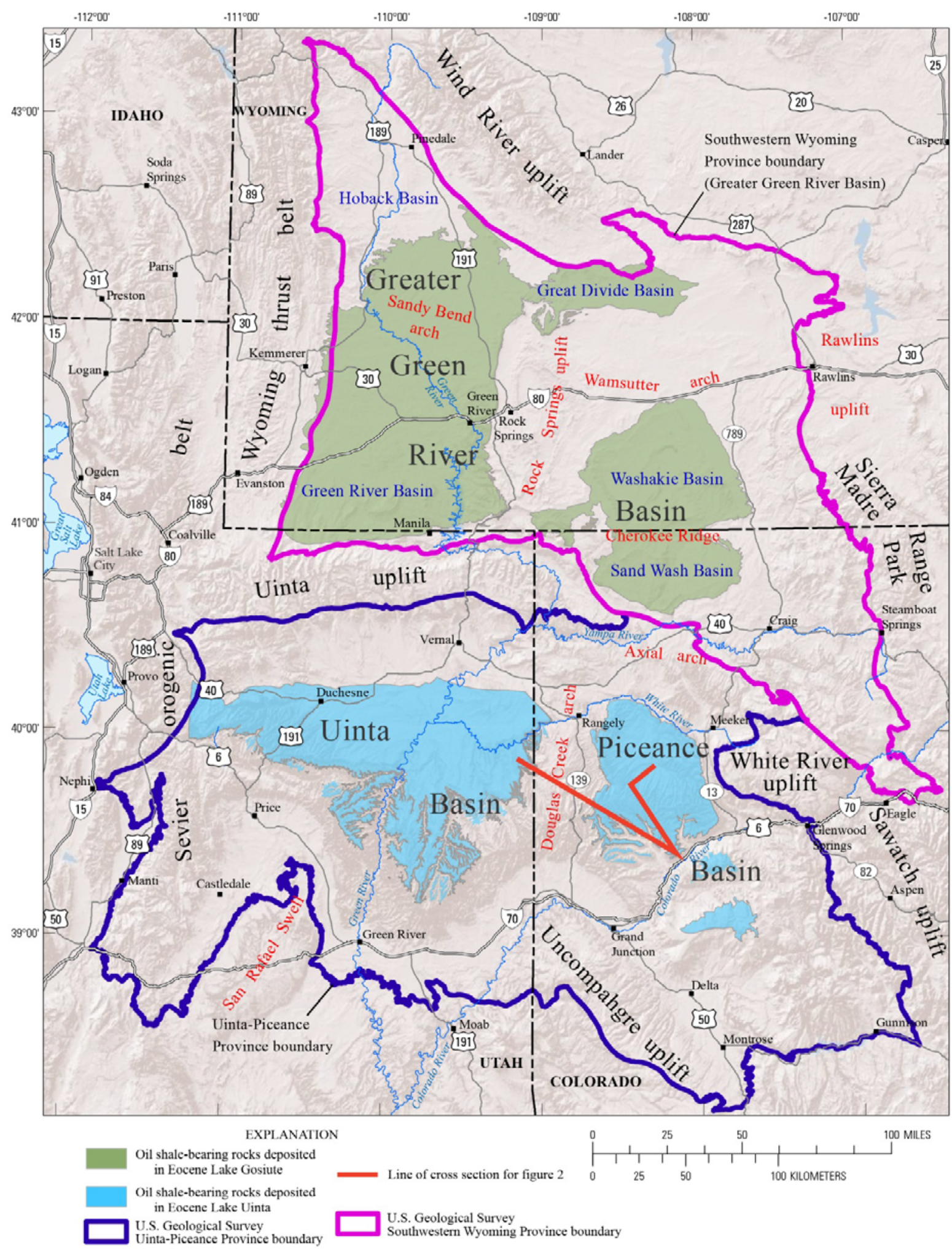

Figure 1. Map showing the extents of Uinta, Piceance, and Greater Green River Basins and approximate extent of oil shale in the Eocene Green River Formation. Modified from Mercier and Johnson (2012). 


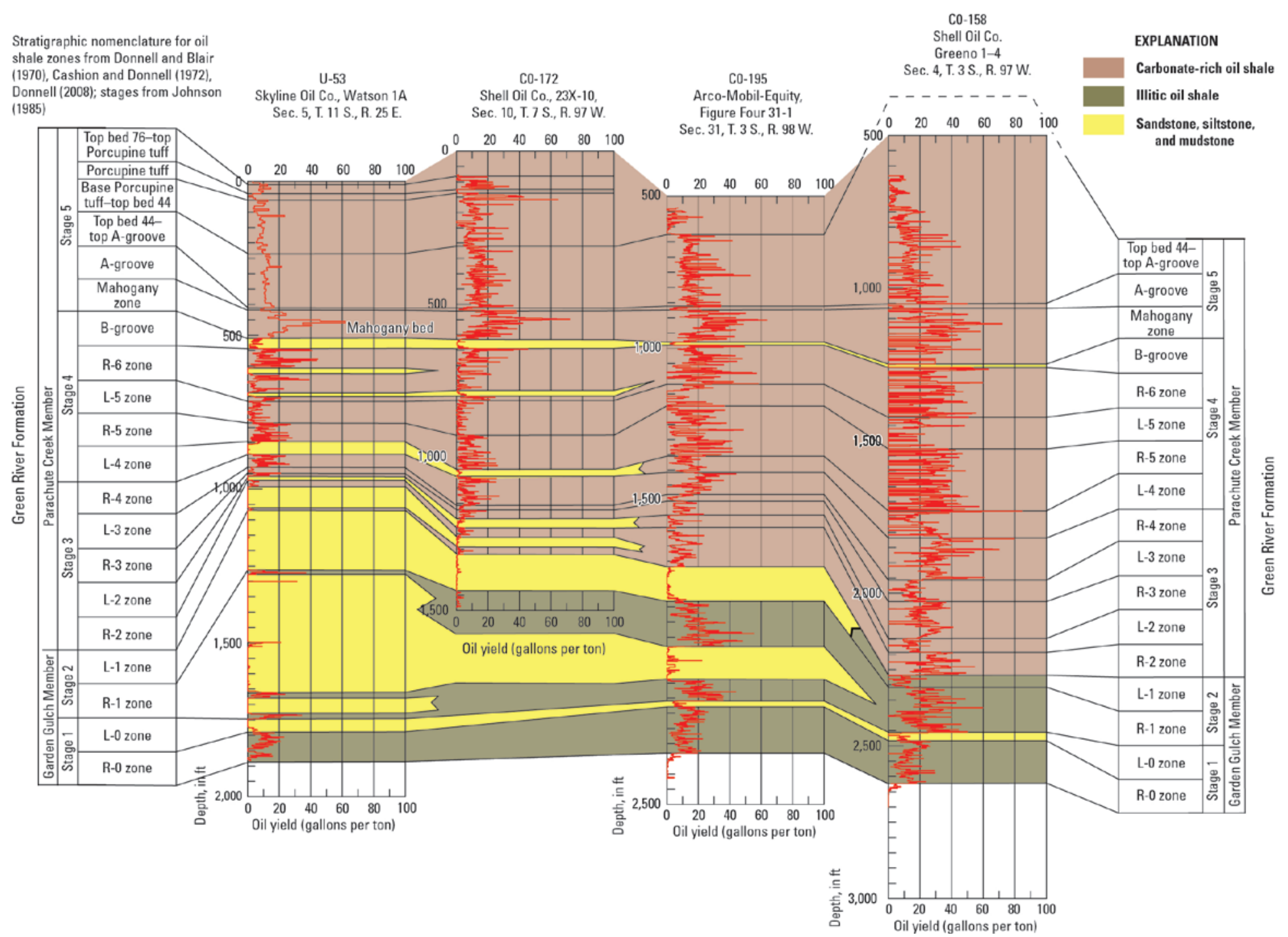

Figure 2. Cross section showing members of the Eocene Green River Formation, stages in the evolution of Lake Uinta, correlation of rich (R) and lean (L) oil shale zones of Cashion and Donnell (1972), and oil-yield histograms. Line of cross section is indicated on figure 1. Modified from Mercier and Johnson (2012). (ft, feet) 


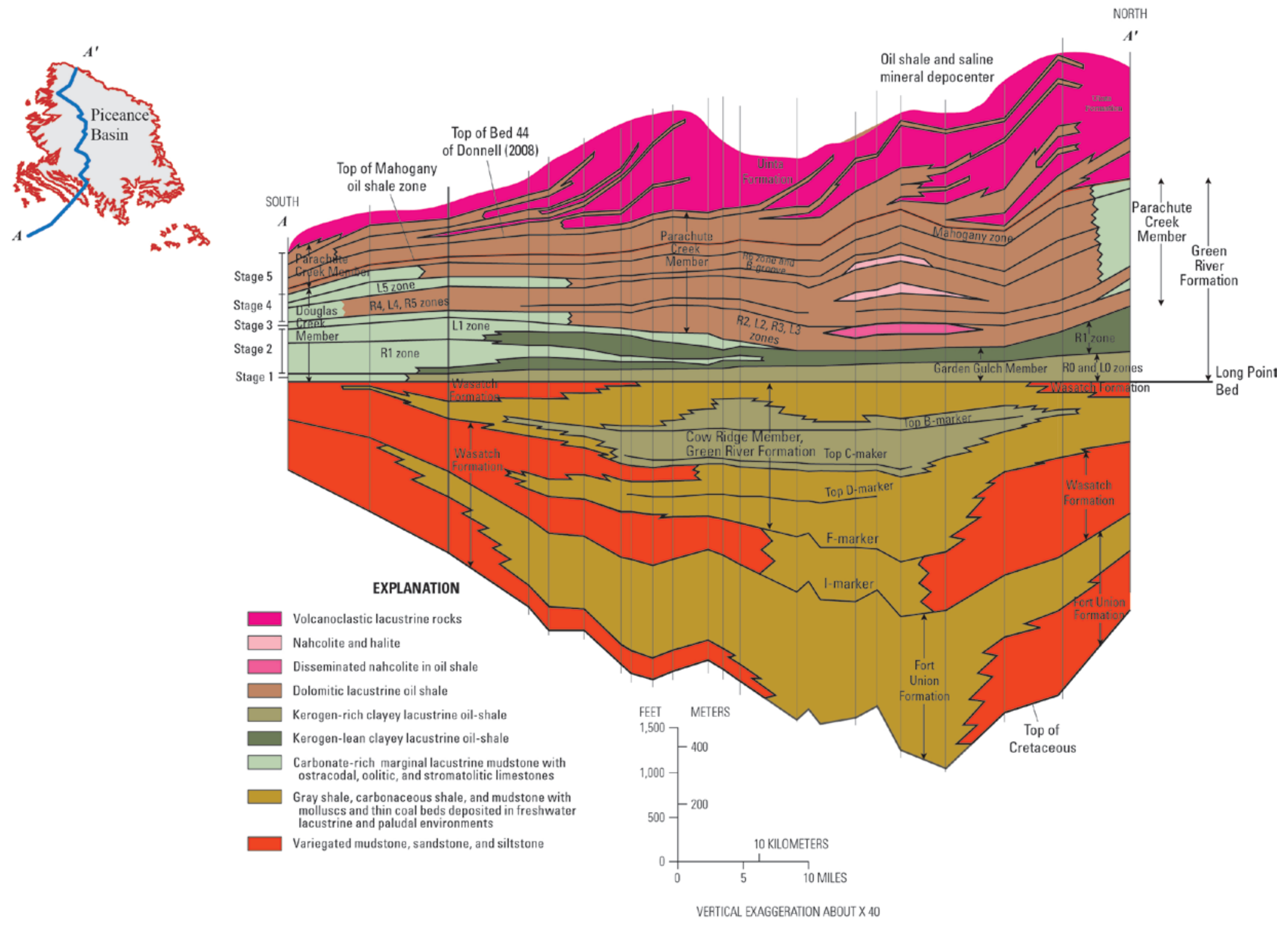

Figure 3. North-south cross section through the Piceance Basin, northwestern Colorado, showing stratigraphic subdivisions, stages of Lake Uinta as defined by Johnson (1985), and some of the rich and lean zones defined by Cashion and Donnell (1972). Modified from Johnson (2012). 


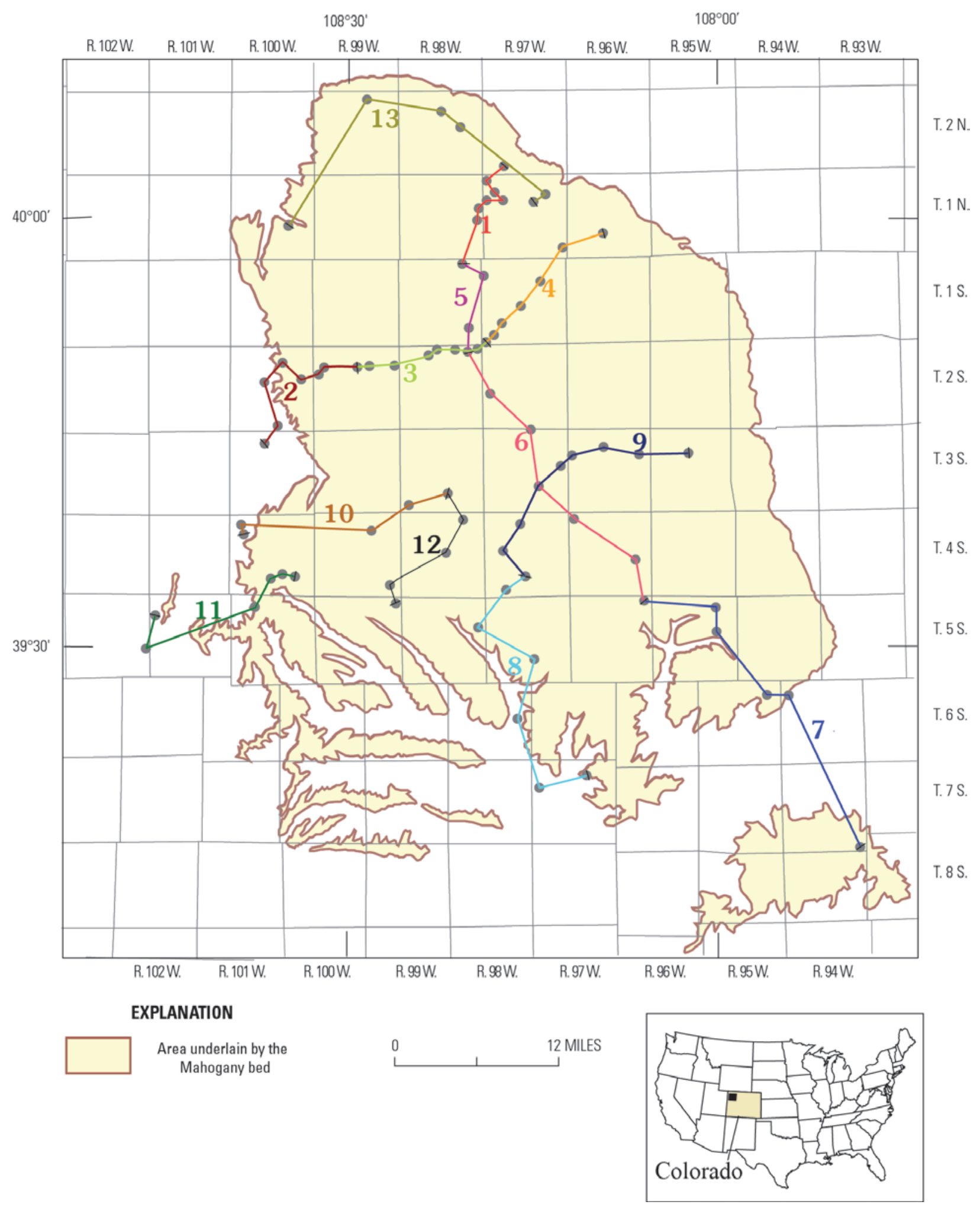

Figure 4. Map showing locations of the 13 stratigraphic cross sections in the Piceance Basin, Colorado. Modified from Self and others (2010). 

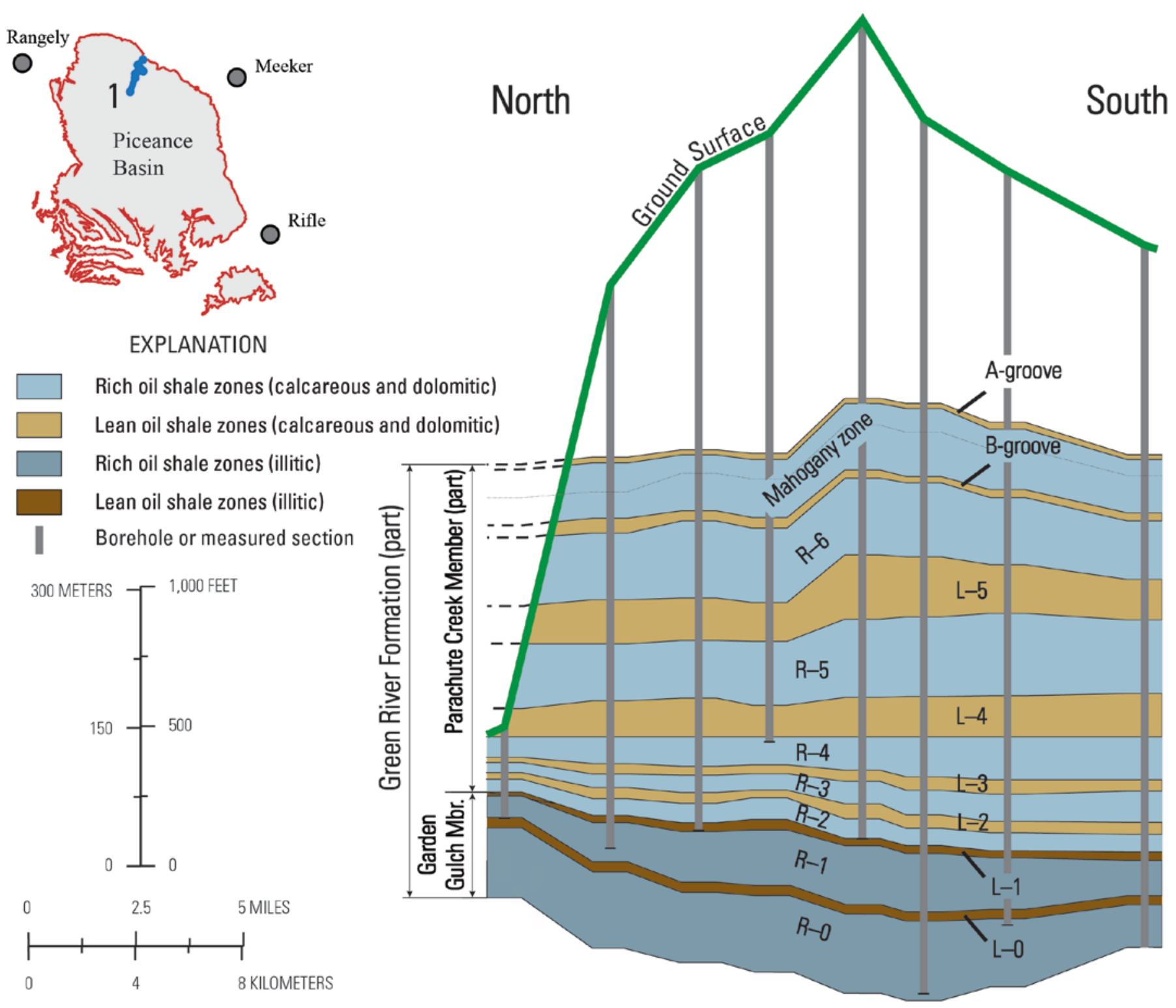

Figure 5. Cross section line 1. Modified from Self and others (2010). 

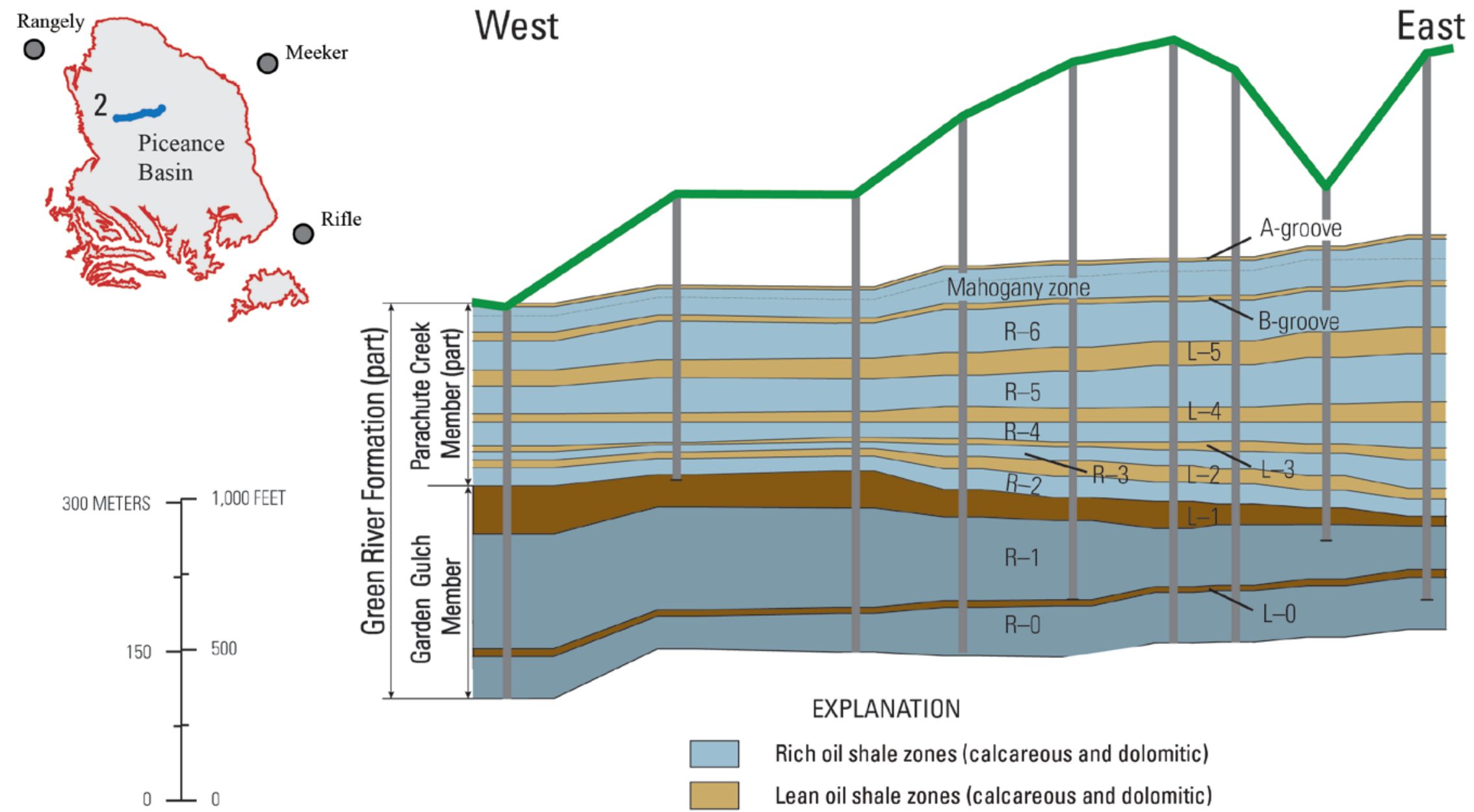

Rich oil shale zones (calcareous and dolomitic)

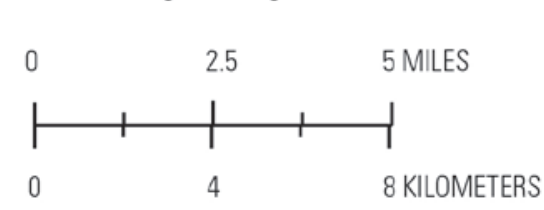

Lean oil shale zones (calcareous and dolomitic)

Rich oil shale zones (illitic)

Lean oil shale zones (illitic)

Borehole or measured section

Figure 6. Cross section line 2. Modified from Self and others (2010). 


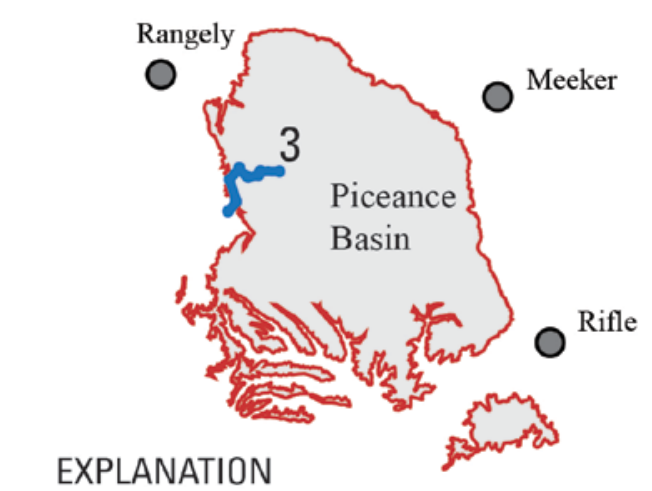

Rich oil shale zones (calcareous and dolomitic) Lean oil shale zones (calcareous and dolomitic) Rich oil shale zones (illitic) Lean oil shale zones (illitic) Borehole or measured section
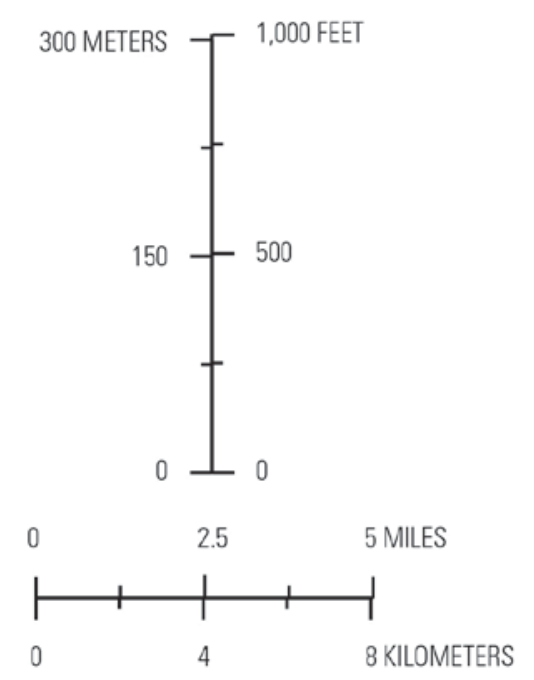

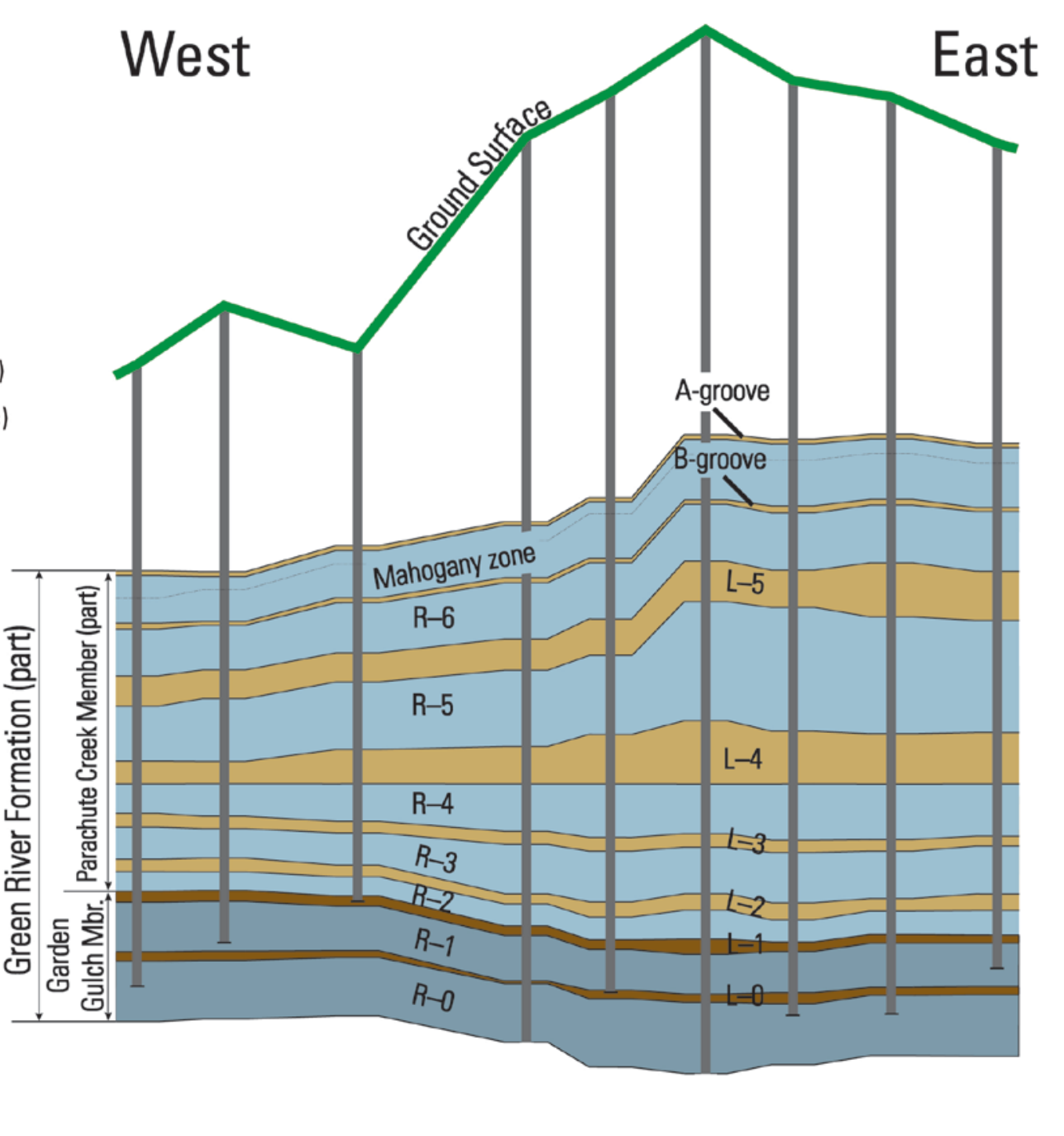

Figure 7. Cross section line 3. Modified from Self and others (2010). 


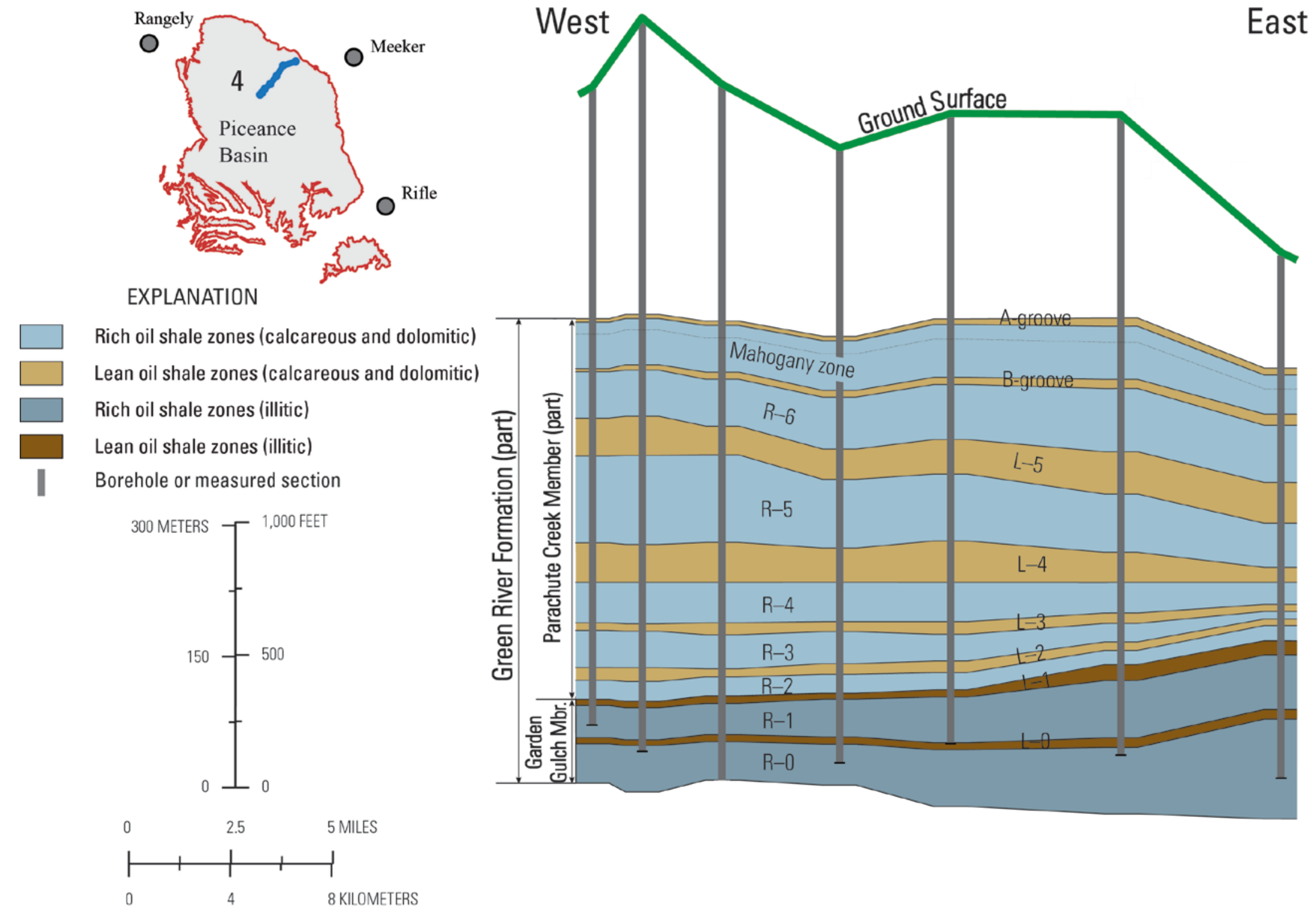

Figure 8. Cross section line 4. Modified from Self and others (2010). 

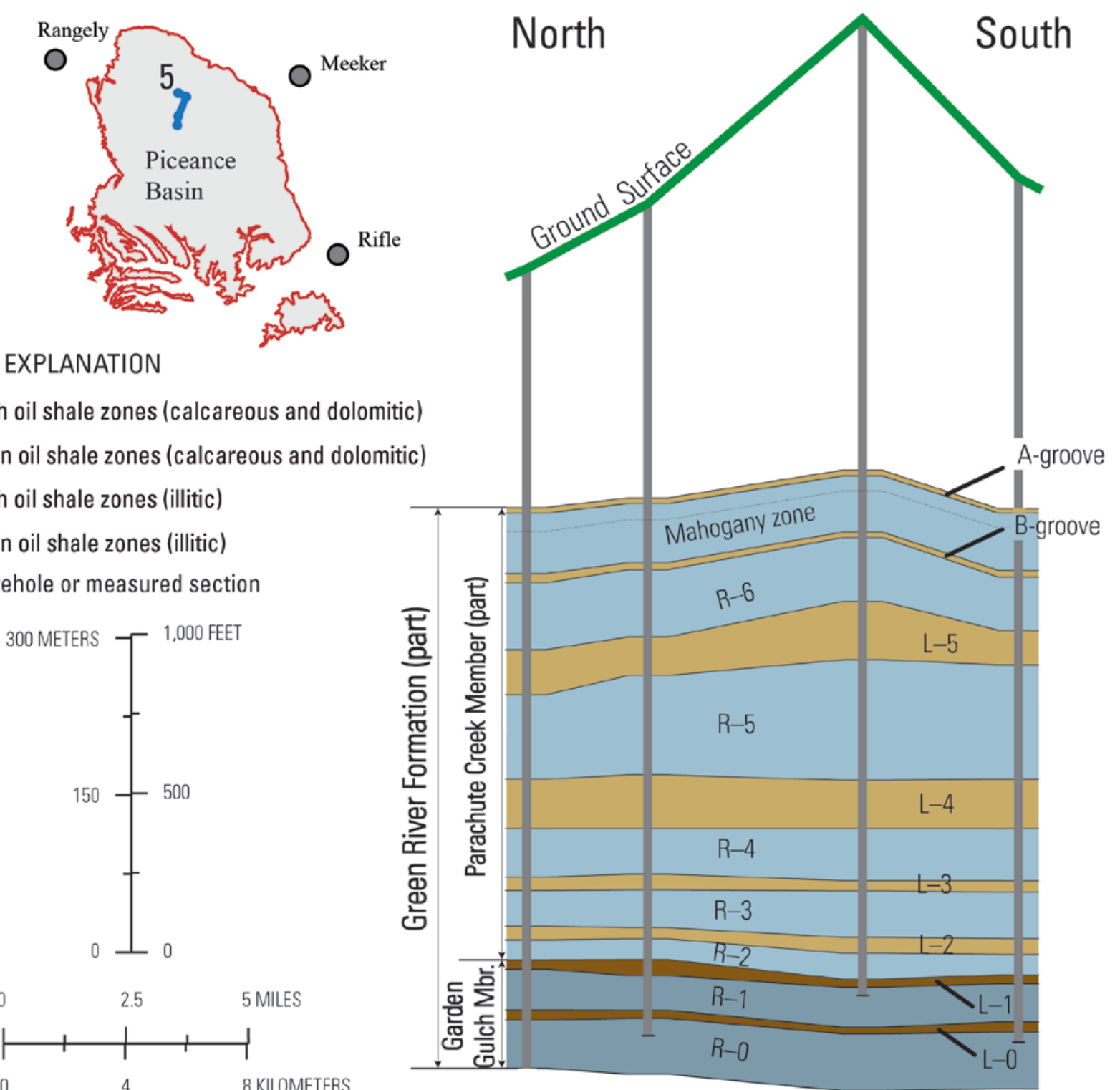

Figure 9. Cross section line 5. Modified from Self and others (2010). 


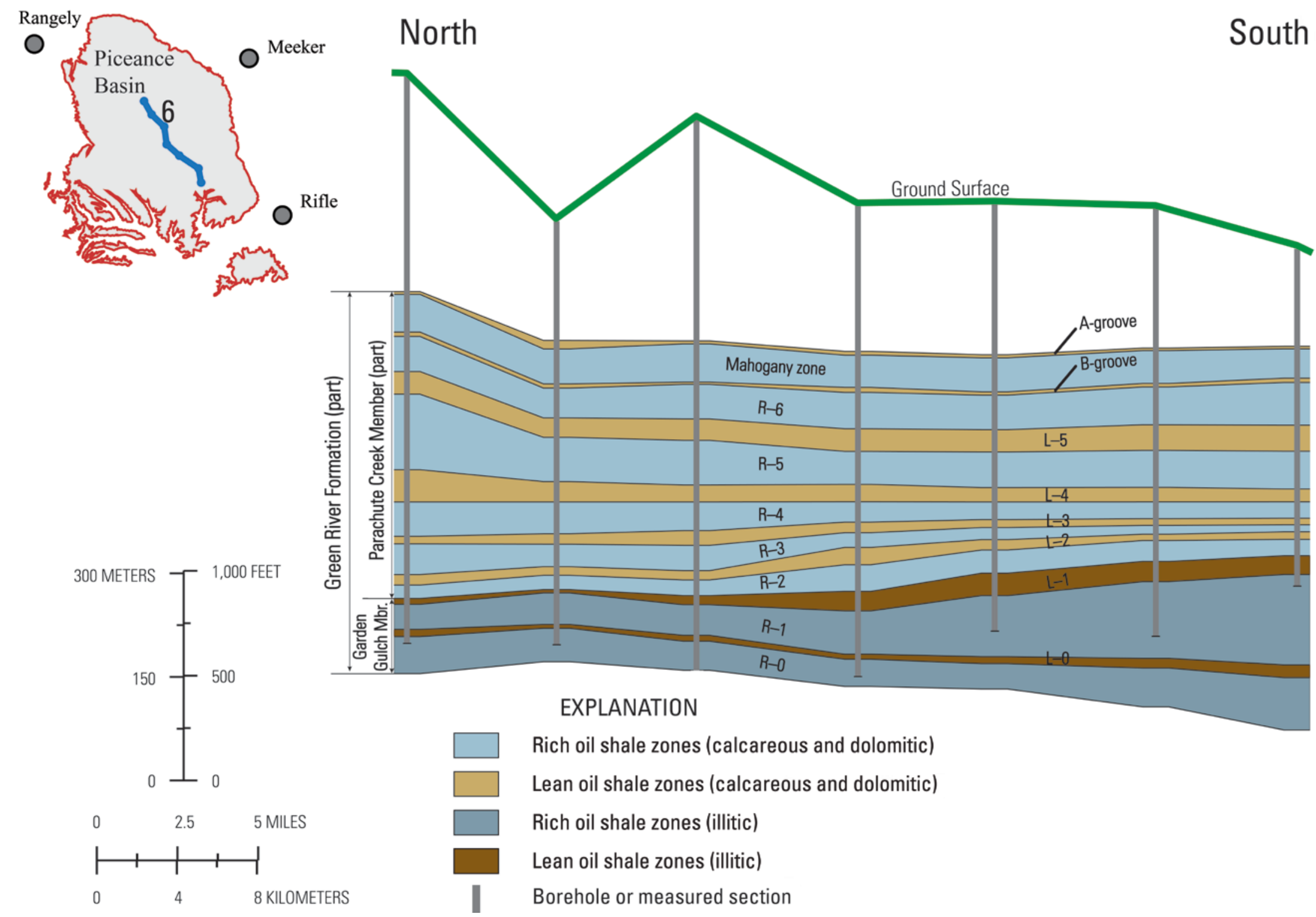

Figure 10. Cross section line 6. Modified from Self and others (2010). 


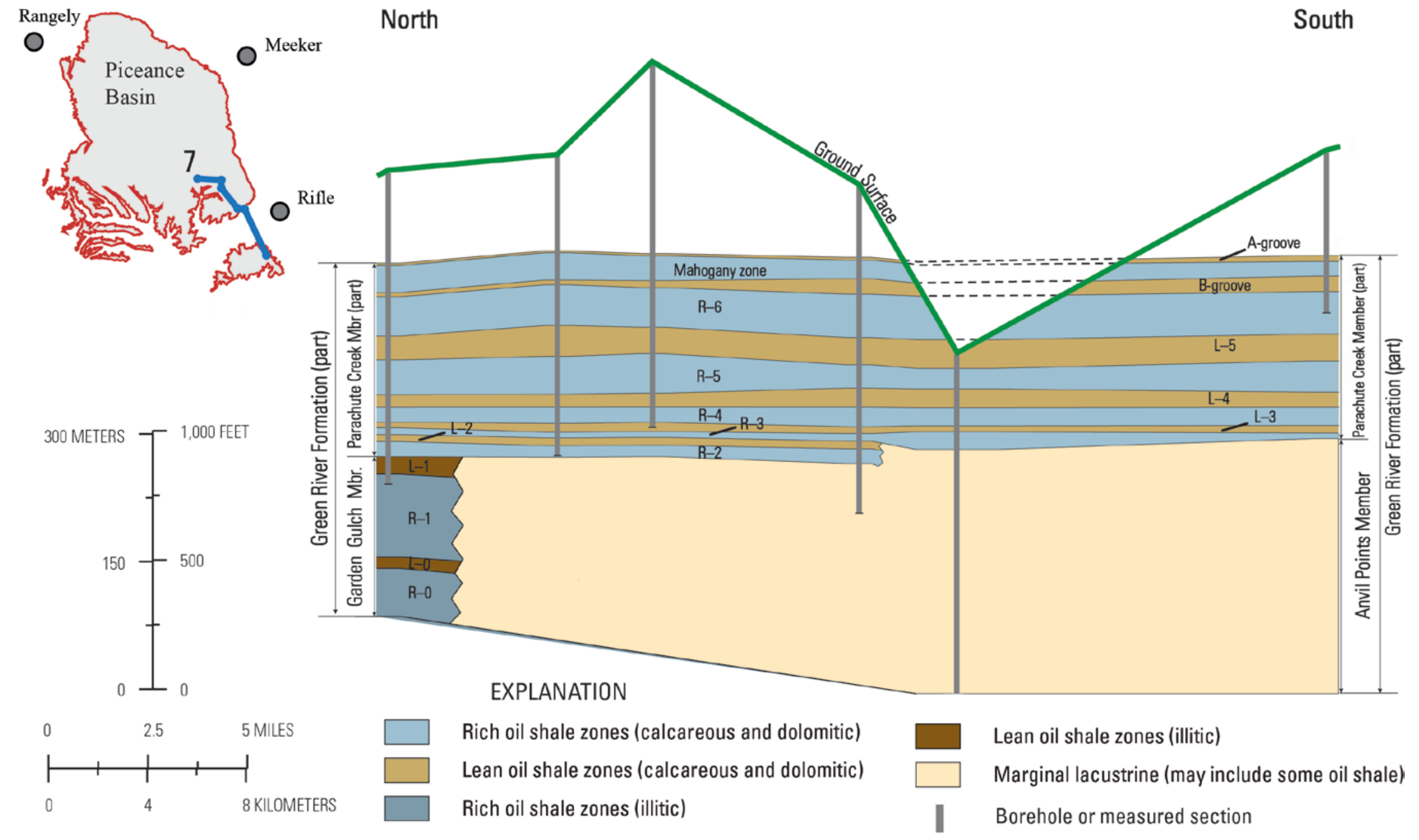

Figure 11. Cross section line 7. Modified from Self and others (2010). 


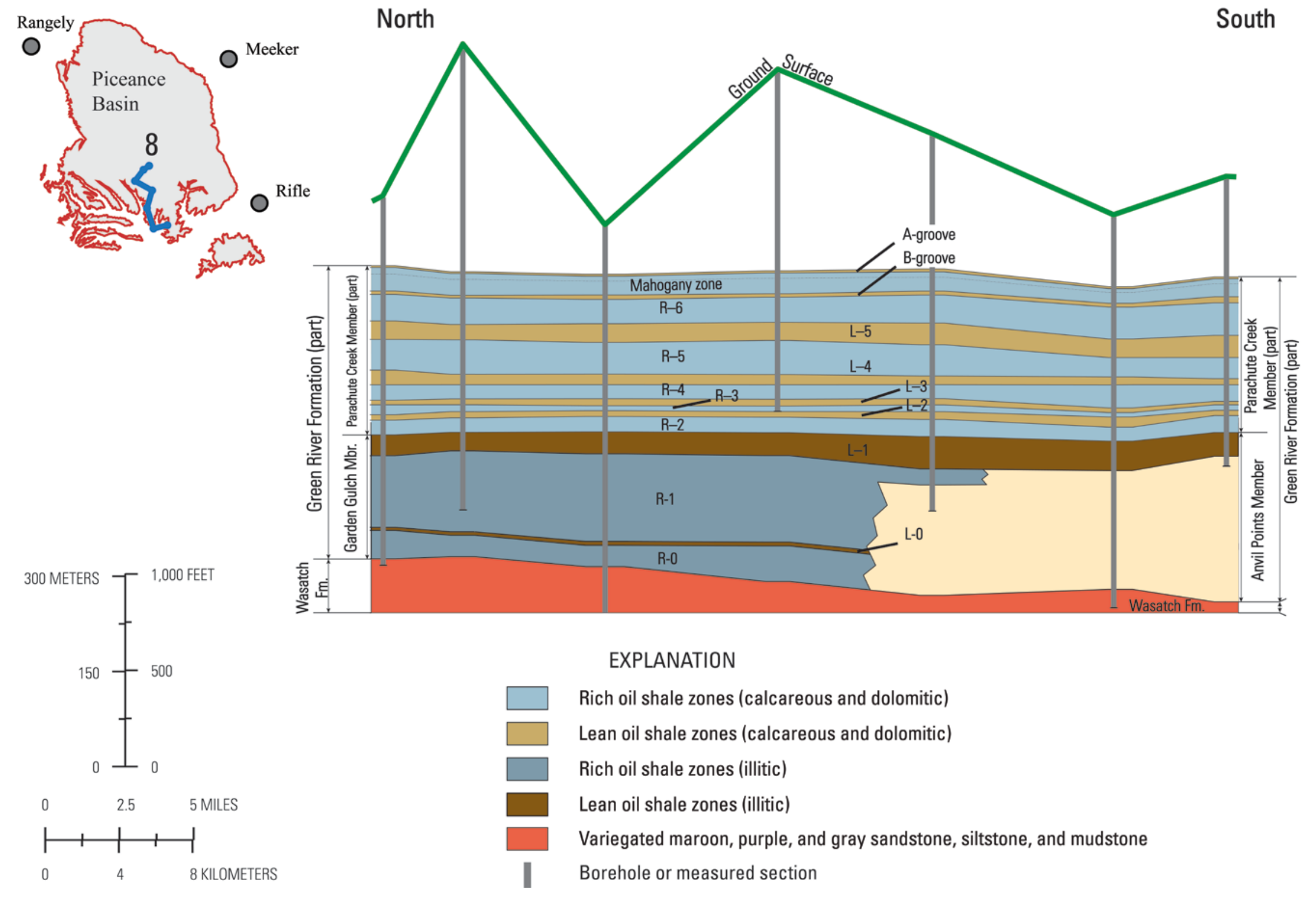

Figure 12. Cross section line 8. Modified from Self and others (2010). 


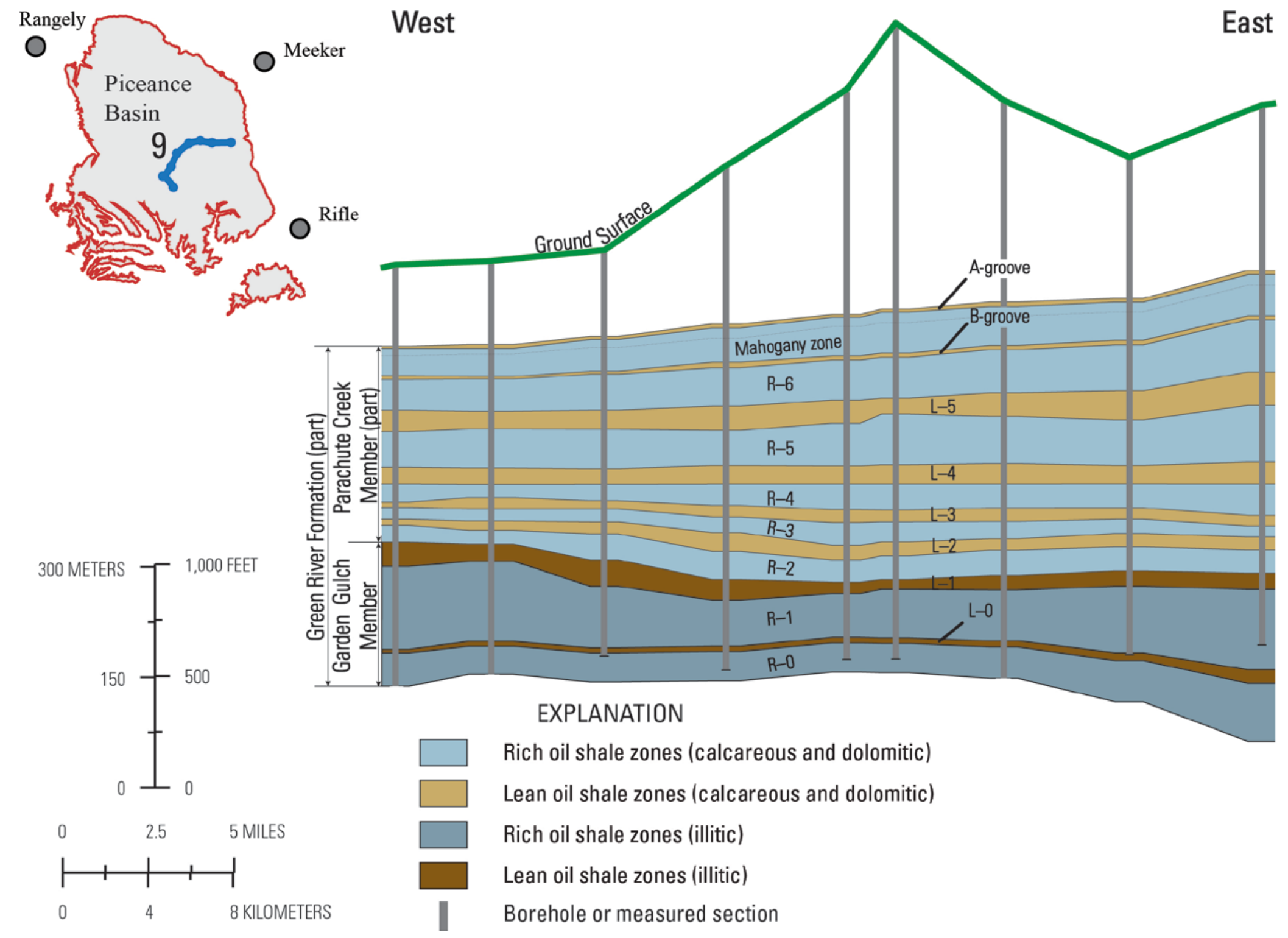

Figure 13. Cross section line 9. Modified from Self and others (2010). 


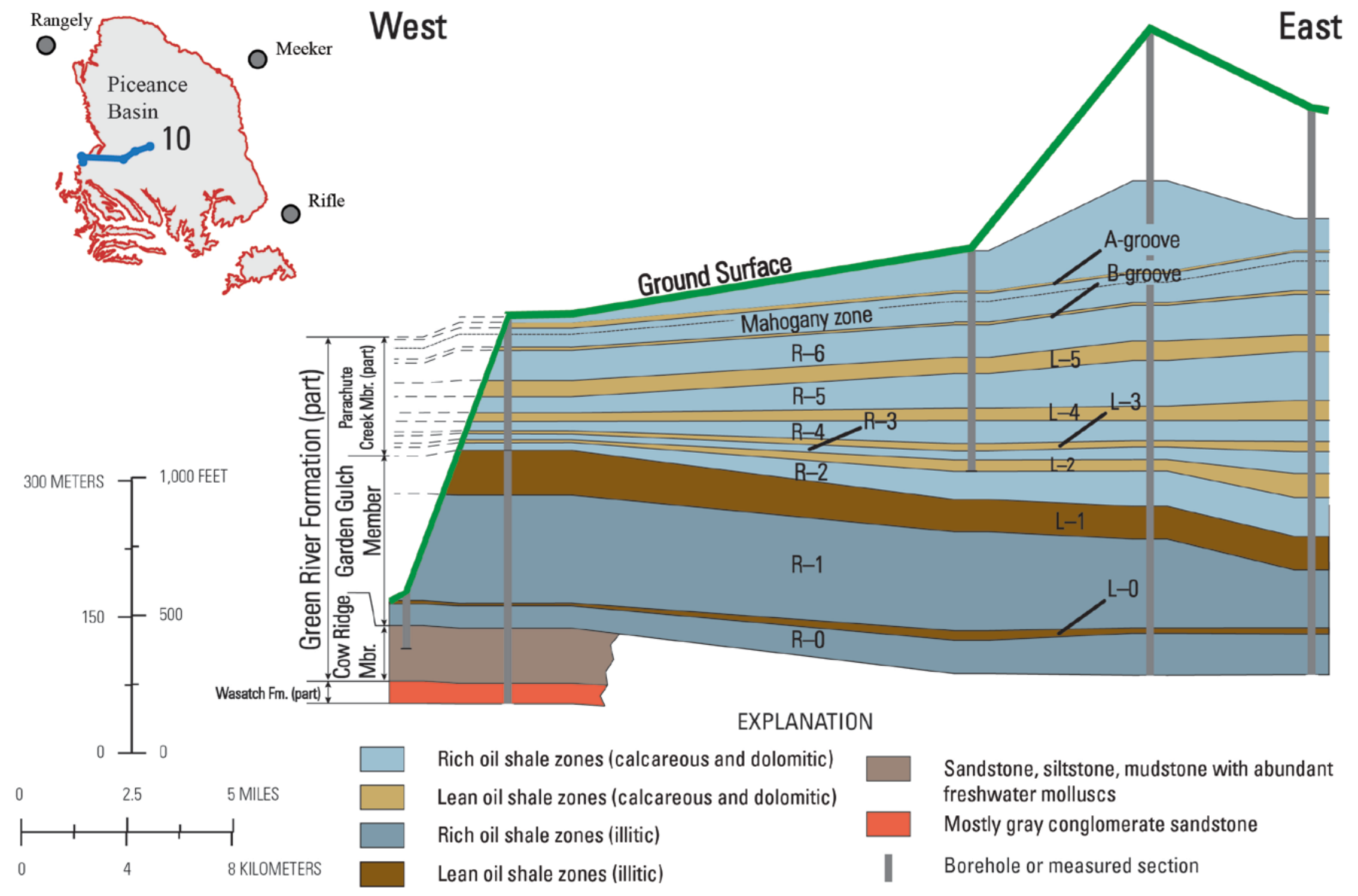

Figure 14. Cross section line 10. Modified from Self and others (2010). 


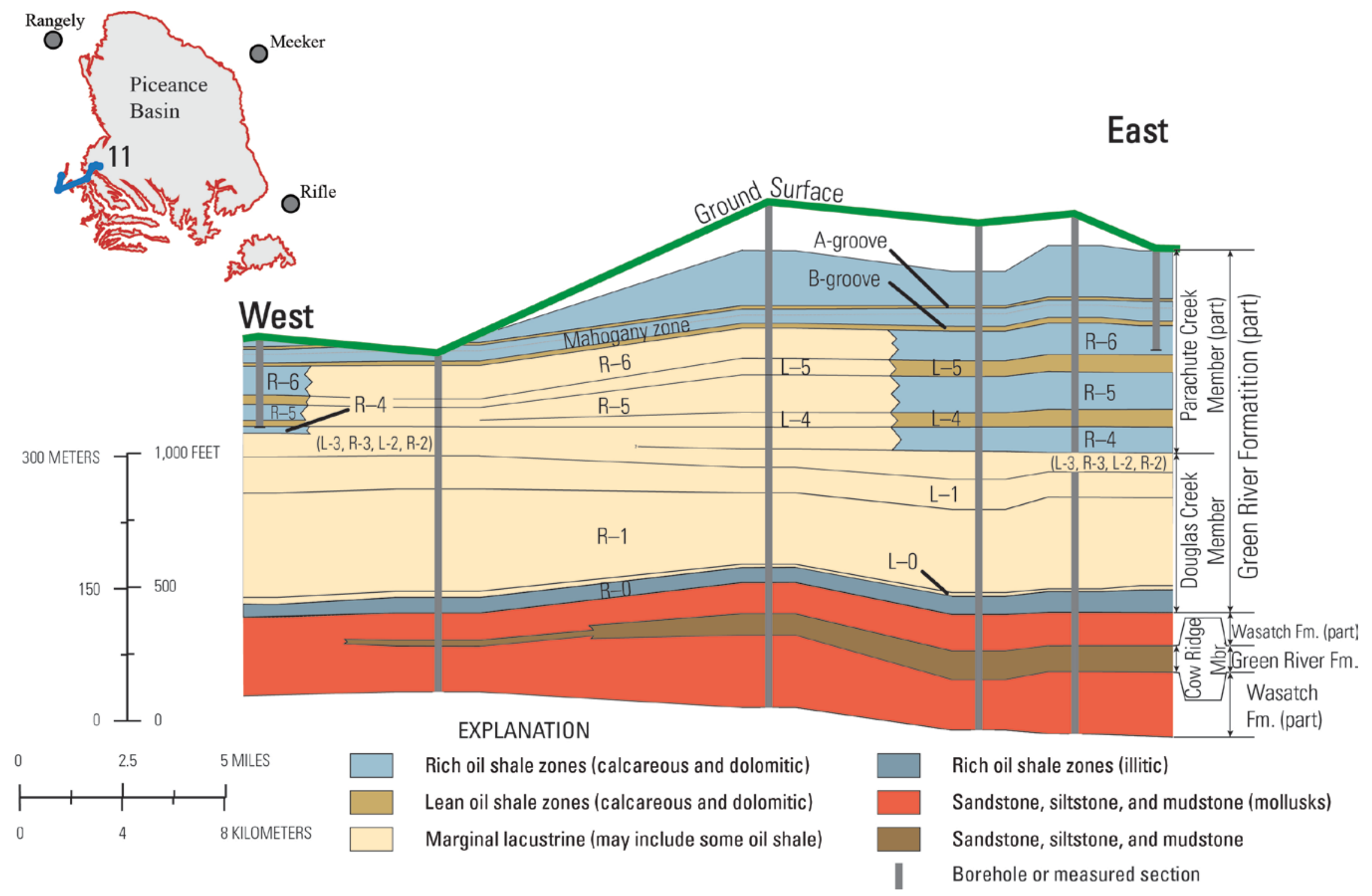

Figure 15. Cross section line 11. Modified from Self and others (2010). 


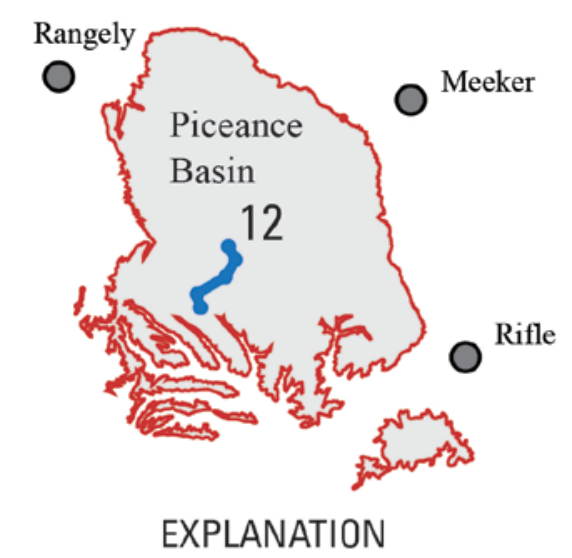

North

South

Rich oil shale zones (calcareous and dolomitic) Lean oil shale zones (calcareous and dolomitic) Rich oil shale zones (illitic)

Lean oil shale zones (illitic)
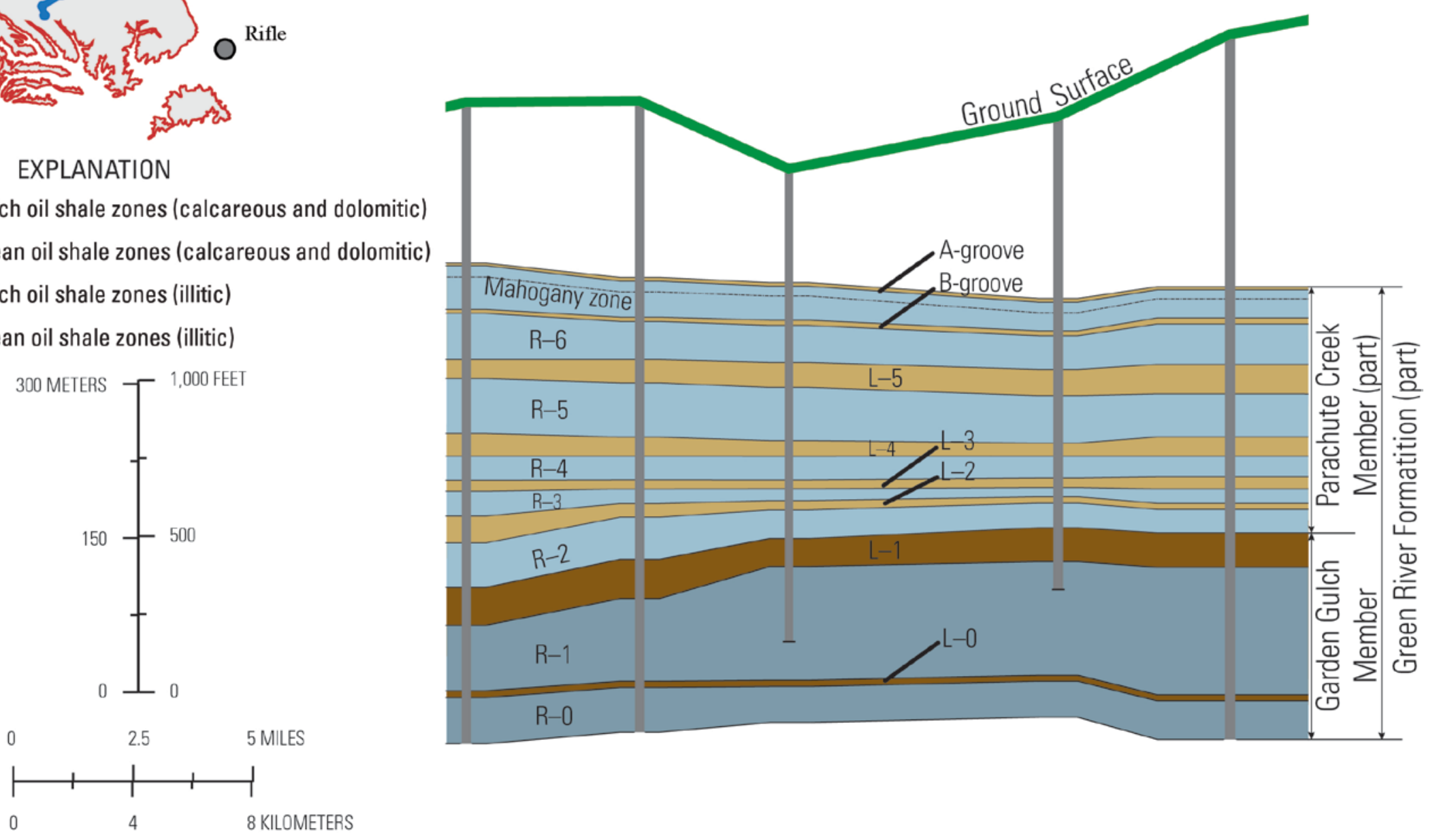

Figure 16. Cross section line 12. Modified from Self and others (2010). 


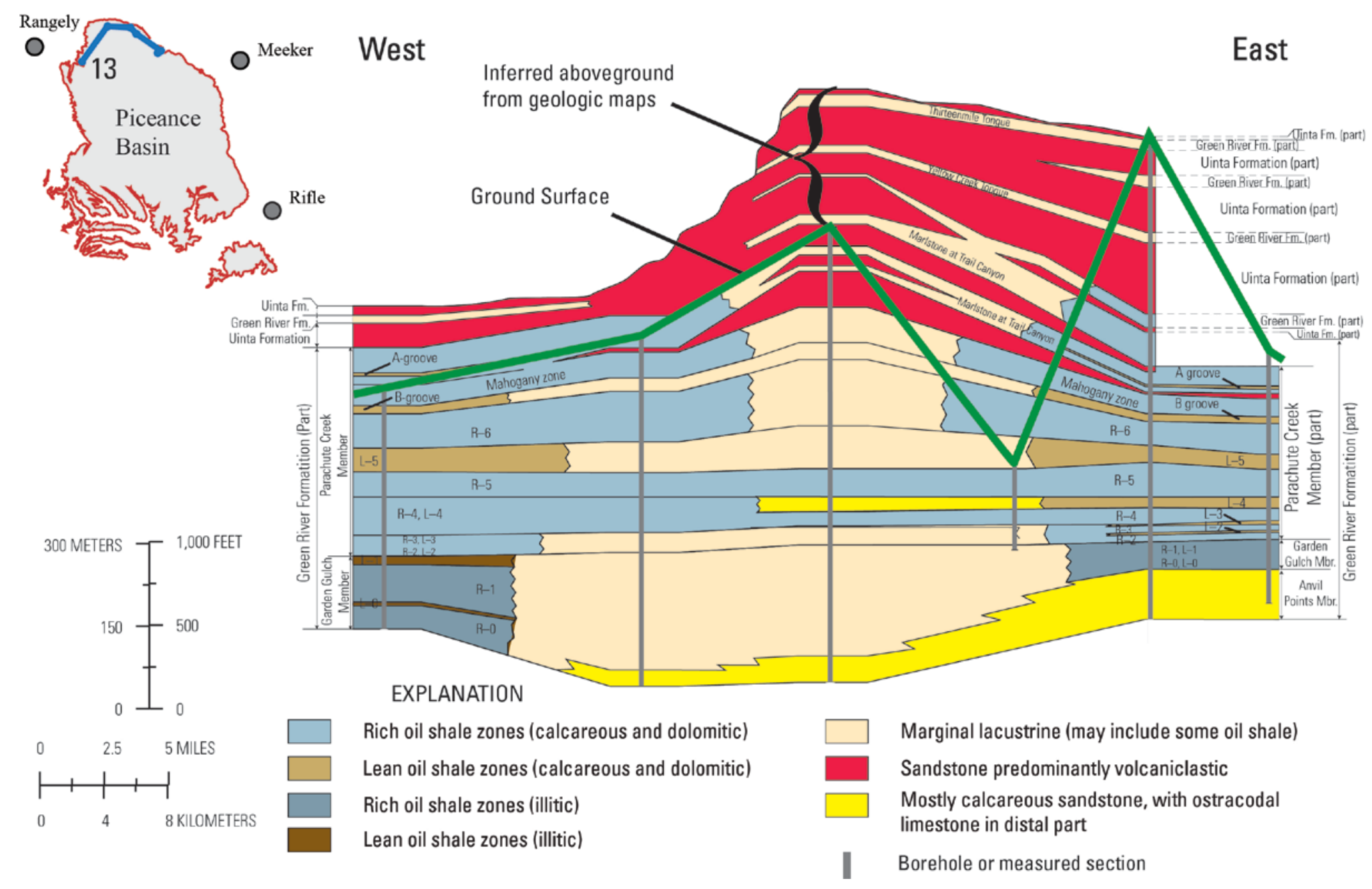

Figure 17. Cross section line 13. Modified from Self and others (2010). 